\title{
COMPARATIVE ANALYSIS OF TRADITIONAL FORMS OF MARRIAGE IN UZBEK- KAZAKH ETHNOCULTURAL PROCESSES (ON THE EXAMPLE OF THE TASHKENT OASIS)
}

\author{
Oybek Salimakhamatovich Artikbaev
}

Researcher Institute Of Retraining And Advanced Training Of Specialists In Physical Culture And Sports, Uzbekistan

\section{ABSTRACT}

This article provides a comparative analysis of the types, commonality, ethnicity and ethnicity, regional features and interactions of traditional forms of marriage in ethnic processes of the Uzbek people and Kazakh ethnic groups in the Tashkent oasis.

KEYWORDS: - Ethnos, marriage, ethnic group, seed, family, tradition, ritual, exogam, endogam, sorority, levirate, thick, ethnoculture.

\section{INTRODUCTION}

The Uzbek people have always had ethnocultural relations with the Tajik, Kyrgyz, Karakalpak, Turkmen and Kazakh ethnic groups. Such relations have their own peculiarities in one of the ancient historical and cultural regions of Uzbekistan - the Tashkent oasis. This uniqueness can be seen in the example of ethnic and cultural relations and interactions of the Uzbek-Kazakh peoples located in the ethnocultural region or in the territory of ethno-dialogue.

Despite their ethnic and political boundaries, the inter-ethnic ties and relations between these two peoples go back a long historical period. These peoples, whose historical roots are Turkic, have many peculiarities in their family and marriage relations and related customs, as well as commonalities.
Forms and customs of marriage, firstly, as a small element of the culture of each ethnos, are the product of long-standing ethnogenetic and ethnocultural ties of this ethnos with other ethnos or ethnic groups, and secondly, the ethnogenesis, ethnic history and historicalcultural roots of Central Asian peoples because it is. This process is also reflected in family traditions, ceremonies, and marriage ceremonies that are part of the spiritual culture.

\section{THE MAIN FINDINGS AND RESULTS}

In the Tashkent oasis, the commonality of the Uzbek-Kazakh peoples in the family, traditional forms and customs of the twentieth century is reflected in the following aspects.

- in the unity of their historical core;

- in the formation of a single territorial unit or in a regional character. 
DOI: https://doi.org/10.37547/history-crjh-02-10-10

ISSN 2767-472X

(C)2021 Master Journals

\section{Crossref do: 81 Google}

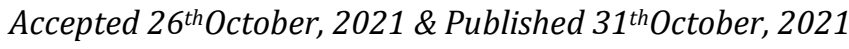

The above-mentioned commonalities are reflected in the life of the Uzbek and Kazakh peoples and also express ethnicity. The ethnicity in them is manifested under the influence of the predominance of sedentary or nomadic culture.

Researchers dealing with family issues confirm that the remnants of patriarchal and hereditary regimes have been preserved in the family and marriage relations of Uzbeks, Kazakhs and other indigenous peoples, as well as in the customs and rituals associated with it. Such aspects of the past are still present in family traditions and ceremonies, starting with the structure of the family.

There are two main forms of the family in the peoples of Central Asia and Kazakhstan: one is referred to in the scientific literature as "large patriarchal families" and the other as "small or ordinary families". One of the researchers dealing with family issues, T.H. Tashboeva, M.D. Savurovs point out that even in the early twentieth century, there were large patriarchal families, and the average number of family members was 10-12 people [1]. M.A. Bikjanova notes that the number of people in very large families can reach 60-70 or even 100 [2]. In the Tashkent oasis, such large families can be called an undivided family or a family of very close relatives. Such families are divided into small families as a result of the influence of the socioeconomic situation of the 20-30s of the XX century. This process takes place among the population (Uzbek, Tajik, Kurama, Kazakh) who have been living together in the oasis for several years.

However, in the 1920s and 1930s, Kazakh ethnic groups settled in the Chinaz district of Kazakhstan, where there were large patriarchal families that lived undivided until the 1950s[3]. This is because in the Kazakh ethnic groups, firstly, the traditions of kinship and sectarianism were very strong in relation to the local population, and secondly, in the ethnic groups that came from other places, they merged and self-isolated.

It should be noted that the above-mentioned family forms are specific to all ethnic groups and communities, although not to the same extent, regardless of the lifestyle and economic orientation of the population.

During the period under study, several historical forms of marriage were preserved among the population of the Tashkent oasis. For example, "exogam" (marriage with members of the family), "endogam" (marriage between close relatives), these include forms of marriage, such as "sorat" (marriage of a widow to his sister) and "levirat" (marriage to the wife of a widowed brother or sister). It should be noted that "endogam" and "exogam" marriages are approved by the Uzbek, Tajik and Uyghur peoples. In Kazakhs, Kyrgyz, and Karakalpaks, endogamous marriages are not allowed. They forbid "exogam" marriage for a certain generation. The ban on "exogam" marriages varied among Kazakhs in the Kazakh region. For example: I. According to Altinsari, in the second half of the 19th century, Kazakhs in northwestern Kazakhstan were banned by their fathers until the eighth generation, and in Northeastern Kazakhs, the ban on "exogam" marriages was imposed until the third generation in the 1980s. In the Syrdarya Kazakhs, the barrier to "exogam" marriage has changed. In the late 19th century, the "exogam" barrier was established until the seventh generation, but by the beginning of the 20th century, it was considered possible to marry even after three or four generations [6].

In general, in Kazakhs, the barrier to "exogam" marriage is a strict rule that must be observed from the fifth to the fourteenth generation. If 
DOI: https://doi.org/10.37547/history-crjh-02-10-10

ISSN 2767-472X

(C)2021 Master Journals

\section{Crossref doi) 81 Google}

Accepted $26^{\text {th }}$ October, 2021 \& Published $31^{\text {th }}$ October, 2021

anyone violated this rule, he was first discussed in the council of elders and fined or sentenced to death. [7] Now they are embarrassed in public, abandoned by their relatives and expelled from the village [8].

In the Kazakh ethnic groups in the Tashkent oasis, the ban on exogamous marriage was imposed until the seventh generation in the early $\mathrm{XX}$. But by the end of the twentieth century, according to the analysis of field data, the exogamous barrier was also observed until the fifth generation. This was due to the influence of local Uzbek traditions. A similar situation can be observed in Kyrgyzstan. In the Fergana Valley Kyrgyz, who settled under the influence of Uzbeks and Tajiks in the late 19th and early 20th centuries, the number of marriages increased even after two generations.

As we have already mentioned, the "levirat" form of marriage is one of the most common marital rights in Asia. In the early twentieth century, remnants of the "levirate" form of marriage are also observed among the peoples of the Tashkent oasis. In the Kazakhs, a woman whose husband had died could marry one of her brothers or one of her close relatives. That is, "If the elder brother dies, the younger sister dies" (if the older brother dies, his wife is in the care of his brother, and if the brother dies, his wife is in the care of his brother). The main purpose of this was an economic issue, thick, dowry and finally related to the fate of children. The woman whose husband had died was thought to have had to return part of the dowry. The widow, who was unable to do so, followed the "levirat" custom.

In the period we are studying, in semi-nomadic Kazakh women, such as settled Uzbek and Tajik women, after the death of their husbands, the obligation of thick return is abolished in the woman and the widow remains free. Only, on the basis of etiquette, he does not marry for a year or two, that is, he is considered a mourner. During this period, the widow had, depending on the circumstances, living with her children in the house left by her husband, moving to another house, or returning to her siblings' home. From this it can be seen that by the twentieth century, the practice of "levirat" was not strict and was abolished.

"Sororat" is a right of marriage, found among settled and nomadic peoples. In the period under study, it is almost non-existent in the Uzbek, Kazakh and Tajik peoples. In addition, one of the traditional forms of marriage in Uzbek, Kazakh, and other nations is infant marriage, in which two families marry before the baby is born (in the mother's womb) or in the cradle. In the Kazakhs of the Tashkent oasis, like the Uzbeks, it is called "belkuda" and "beshik kuda" or "besik kuda". This custom is called "aqloy kuda tusu" in Fergana Karakalpaks. For example, in the case of "bel kuda" and "besik" kuda in Kazakhs, it was not necessary to pay a thick. If the waist is dropped, the guy kidnaps the girl, then he is paid less thick than the usual thick amount.

The thick issue was of great importance for marriage. The peculiarities, amount and type of the thick payment are clearly manifested between the settled-peasant (Uzbek) and nomadic (Kazakh) peoples, who have two different forms of economy. This situation continued in the Kazakhs of the Tashkent oasis in the early twentieth century. But as a result of the collectivization policy of the 1930s, the pastureland was used for agriculture, the number of livestock decreased, semi-settled Kazakh ethnic groups settled, and the settlement was integrated with the settled economy. This has also had an impact on the issue of selfpayment. For example, at the beginning of the twentieth century, the Kazakh rich paid 47 heads of selected cattle, while the poor paid 7 heads of cattle [11]. By the end of the twentieth century, 
DOI: https://doi.org/10.37547/history-crjh-02-10-10

ISSN 2767-472X

(C)2021 Master Journals

\section{Crossref doi) 81 Google}

Accepted $26^{\text {th }}$ October, 2021 \& Published $31^{\text {th }}$ October, 2021

the amount of fat had changed to $2-3$ head of cattle or 1-1.5 million soums [12]. In the Kazakhs of the Tashkent oasis, the amount, composition and attitude to it has changed. They began to pay for the thick not only with livestock, but also, like local Uzbeks, with agricultural products and money. As a result of their activation of farming in relation to cattle breeding, the amount of fat gradually decreased.

As a result of the thick payment condition and the size of the amount for the bride, there were several different ancient peculiarities among the population. These include the "groom", "game" and "bride kidnapping".

Among the poor stratum of the Kazakhs there was a custom of paying thick by working in marriage. In it, the father of the bride lived in his house and served on his farm for several years. They called the adopted groom "kush kuyov" "ishchi kuyov", "kushik kuyov" - "it kuyov" or "kirme kuyov" - "begona kuyov". This custom existed in the Kazakhs of the Tashkent oasis in the early twentieth century, and in recent times has remained very rare among the population.

In the early twentieth century, the roots of the tradition of "kalliq oyun" were preserved in the Uzbek, Kazakh, Kyrgyz and Karakalpak peoples. This custom, known in Uzbek as "kalliq oyun", in Kazakh as "jasirin boru", "urin kelyu" or "qoshdiq ounau", in Kyrgyz as "kyuyyoeloyo boruu", and in Karakalpak as "kuyelep juru", is similar in content to all peoples [9]. This habit is almost non-existent among the Uzbeks of the Tashkent oasis at the time of our study. But among the Kazakhs it was partially preserved.

Another habit associated with boldness in Kazakhs is the practice of "kidnapping" This custom is found not only in the Kazakh, but also in the Kyrgyz and Karakalpak peoples. According to field data, the practice of "bride kidnapping" in the period we are studying is reflected in the
Kazakhs of the Tashkent oasis in the following forms:

- the young man was abducted with the consent of the bride, failing to pay taxes related to the marriage and the bride;

- the young man was able to pay the thick, and the girl's parents agreed, but the girl was abducted in displeasure;

- the girl was abducted in a state of ignorance;

- the girl was abducted without her parents'consent;

- the girl was abducted with the consent of both her parents, without informing the girl, following the traditional custom and in order to respect the custom.

In the custom of abducting the girl and her relatives without their knowledge, after the girl was taken away, the boy's sister-in law'swrote a receipt from the girl and an ambassador was appointed to inform the girl's parents. If the girl's father came with her relatives, of course he took her back. It was difficult for the returned girl to marry because she was called abducted. When the girl's relatives arrived, after a quarrel and an argument, a compromise was reached and a gift was given to the guest. The girl was forced to live on fate. This kind of "kidnapping" is very dangerous.

One of the main aspects or factors in the practice of "bride kidnapping" girls in Kazakhstan also depended on the economic capacity of the family. This is because the main advantages of this custom, as we have seen above, are that, firstly, it is thick and tax-free, and secondly, it has ample opportunity for a wedding, even if it is possible to have a wedding after having children.

Among Uzbeks, "bride kidnapping" is rare (one in ten thousand). In it, too, the girl agreed, and when her parents strongly resisted, they fled 
DOI: https://doi.org/10.37547/history-crjh-02-10-10

ISSN 2767-472X

(C)2021 Master Journals

\section{Crossref doi) 81 Google}

Accepted $26^{\text {th }}$ October, 2021 \& Published $31^{\text {th }}$ October, 2021

together in a desperate situation. This practice is strongly condemned by Uzbeks.

Influenced by the way of life and customs of the local population, the practice of "bride kidnapping" in Kazakh ethnic groups is now becoming more common, as is the practice of consensual consent and marriage with the consent of the groom and the sale tax. The historical roots of the "bride kidnapping" tradition go back to the time of the tribal community. This tradition is traditionally based on animal husbandry, and is almost well preserved in ethnic groups with strong seed relations, including the Kazakhs of the Tashkent oasis.

\section{Conclusion}

In conclusion, it should be noted that the Tashkent oasis is of great importance not only as a unique historical and cultural region, but also as an ethno-dialogue area conducive to the interaction of settled and nomadic cultures. As a result of the development of ethnocultural relations, the above-mentioned ethnic aspects of the marriage customs of Kazakh ethnic groups in the Tashkent oasis have become of regional significance in harmony with local traditions. The traditional forms of marriage and related customs of the Uzbek and Kazakh peoples are also important in the development of ethnocultural ties between the two peoples.

\section{REFERENCES}

1. Tashbaeva T.Kh, Savurov M. D New and traditional in the life of a rural Uzbek family. Tashkent; 1989. P. 12.

2. Bikzhanova M.A. Family in the collective farms of Uzbekistan. Tashkent: 1959. P. 24.

3. Field record. Chinoz district, S. Rakhimov j / x, Kazakh aul mahalla 2002.
4. Altynsarin I. Essays on customs during a matchmaking wedding with the Kirghiz of the Orenburg department. Notes of the Orenburg branch of the Russian Geographical Society.-Tashkent:1 1970 P. 104.

5. Makovetskiy P.E. Materials for studying the legal customs of the Kyrgyz. Issue 1Omsk.1886. P. 12.

6. Zagryazhsky G. Legal custom of the Kyrgyz. Materials for statistics of the Turkestan region. Issue IV. SPb., 1876 S. 155; Grodekov N. Kirghiz and Kara-Kirghiz of the Syrdarya region, v. I. Tashkent; 1889 P. 27-28.

7. Argynbaev H. Traditional forms of marriage among Kazakhs // Ethnic history and traditional culture of the peoples of Central Asia and Kazakhstan. Nukus.1989. P. 246.

8. Field record. Boka district, Alkhajar village 2003.

9. Abdullaev U.S. Interethnic processes in the Fergana Valley late XIX-early XX centuries T2005 p. 146; Jumanazarov E. From the history of marriage customs of Kyrgyz and Uzbeks (end of XIX century XX century) // History of Uzbekistan. 1999 № 3, p.51.

10. Malitskiy N.G. Kazakh (ethnographic essay). UzRMDA, F-2231, List-1, Case 49, P. 39.

11. Field record. Yangiyul district, Qirqsadaq district. 2003. 